\title{
RESPONSE OF PUERARIA COVER CROP TO INOCULATION WITH AM FUNGI AND PHOSPHORUS IN UPLAND SOIL OF RUBBER PLANTATION AREAS IN BANGLADESH
}

\author{
M.K. RAHMAN*, S.M. KabiR, G.M. MoHSIN ${ }^{1}$ AND A.H.M.Z. Ali \\ Department of Soil, Water \& Environment, University of Dhaka, Dhaka-1000, Bangladesh \\ Key words: Arbuscular mycorrhizal fungi, Karnajhora Rubber Estate, Phosphorus, \\ Pueraria, Upland
}

The use of leguminous cover crop to provide an excellent formation for the cultivation of tree crop is a standard practice in the plantation sector. ${ }^{(1)}$ This cover crop is the key factor to maintain soil fertility and prevent soil erosion in the rubber plantation. Large areas of upland soils of the greater Chittagong, Chittagong Hill Tracts, Sylhet and Mymensingh districts are under rubber cultivation. Pueraria is grown as ground cover in the above rubber plantations. Pueraria is a leguminous crop. Legumes are able to take up most of their requirement of nitrogen and phosphorus via nodules and endomycorrhiza. This complex tripartite system of host, nodule and endomycorrhizal symbionts has many interesting facets including the genetic make-up of the host and the sources of phosphate utilized by mycorrhizal fungi.(2) Legume root nodules also contain a form of hemoglobin, which must somehow be involved in the nitrogen-fixation process.(3) Usually, rubber planters apply $5.5 \mathrm{~kg}$ P/ha to establish leguminous crop.(4) Arbuscular mycorrhizal (AM) fungi are well-known to improve plant phosphorus nutrition especially in soils of low phosphorus availability.(5-7) No information concerning the effect of AM fungi and phosphorus on growth, dry matter yield and nutrient uptake by Pueraria under edaphic and climatic conditions of Bangladesh is available. Therefore, the objective of this study was to evaluate the effect of inoculation with Glomus mosseae and two levels of phosphorus on growth, nodulation and nitrogen accumulation in Pueraria cover crop grown in upland soils of Karnajhora Rubber Estate, Sherpur, Bangladesh.

Composite soil sample (0 - $15 \mathrm{~cm}$ depth) was collected from 1995 planting areas of Karnajhora Rubber Estate from the hill top. Samples were air dried, ground, sieved $(<2 \mathrm{~mm})$ and stored in polythene bags. Some physicochemical properties of the soil were determined following standard methods. The particle size distribution was: sand $43.2 \%$, silt $33.5 \%$ and clay $23.3 \%$, texture-loam, water holding capacity $26.7 \%$. pH 5.5, organic matter $1.8 \%$, total $\mathrm{N} 0.06 \%$. Available N,P,S,K were 42.0, 4.6, 21.2 and $77.5 \mathrm{mg} / \mathrm{kg}$ soil, respectively.

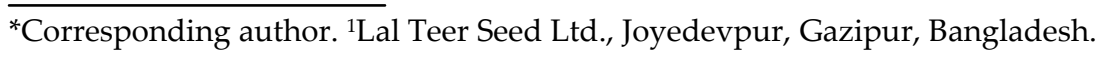


Fifteen hundred gram soil was used per earthen pot $(13 \mathrm{~cm}$ height $\times 19 \mathrm{~cm}$ diameter $)$. Forty gram crude inoculum of Glomus mosseae (fragments of heavily infected maize, root, soil and hypae etc.) were applied to the surface of $1400 \mathrm{~g}$ soil in the pots as a thin layer and then $100 \mathrm{~g}$ soil was spread over the surface of the inoculum. An equivalent amount of soil was added in treatments where no G. mosseae was inoculated. Phosphorus as triple superphosphate was mixed thoroughly with soil at the rates of 2.75 and $5.5 \mathrm{~kg} \mathrm{P} / \mathrm{ha}$. Treatments having three replications were: (i) Control (without G. mosseae and P), (ii) Glomus mosseae (iii) $2.75 \mathrm{~kg} \mathrm{P} / \mathrm{ha}$ and (iv) $5.5 \mathrm{~kg} \mathrm{P} / \mathrm{ha}$. The pots were arranged in a randomized complete block design in a net house in the Department of Soil, Water \& Environment, University of Dhaka. Seeds of Pueraria were soaked in water and six seeds were sown in each pot. Water was added in every morning. The height of the individual plant was measured from the soil level to the tip of the leaflet. Plants were harvested as shoot and root after 35 days of sowing. After washing the roots, root segments of $1 \mathrm{~cm}$ long were stained to evaluate the mycorrhizal colonization. ${ }^{(8)}$ The stained root pieces were observed under a microscope. The presence or absence of infection in the root pieces was recorded and then percentage infection was calculated.(9) Nodules were counted. Shoots and roots were air dried, oven dried $\left(65^{\circ} \mathrm{C}\right)$ for 72 hours, weighed, ground $(<1 \mathrm{~mm})$ in a mechanical grinder and stored in air tight polythene bags. The total $\mathrm{N}$ uptake by roots and shoots was determined using micro-distillation apparatus. ${ }^{(10)}$ Statistical analysis of the results were carried out and repective LSDs indicated at the bottom of the Table 1 .

Table 1. Effects of inoculation with Glomus mosseae and phosphorus on height, dry matter production, root nodules, root colonization and uptake of $\mathrm{N}$ by the shoot and root of Pueraria cover crop.

\begin{tabular}{|c|c|c|c|c|c|c|c|}
\hline \multirow{2}{*}{ Treatments } & \multirow{2}{*}{$\begin{array}{l}\text { Plant } \\
\text { height } \\
(\mathrm{cm})\end{array}$} & \multicolumn{2}{|c|}{ Shoot } & \multicolumn{2}{|c|}{ Root } & \multirow{2}{*}{$\begin{array}{c}\text { No. of root } \\
\text { nodules } \\
\text { (/pot) }\end{array}$} & \multirow{2}{*}{$\begin{array}{c}\text { Root } \\
\text { colonization } \\
(\%) \\
\end{array}$} \\
\hline & & $\begin{array}{c}\text { Dry wt. } \\
\text { (g/pot) }\end{array}$ & $\begin{array}{l}\text { N uptake } \\
(\mathrm{mg} / \text { pot })\end{array}$ & $\begin{array}{c}\text { Dry wt. } \\
\text { (g/pot) }\end{array}$ & $\begin{array}{l}\text { N uptake } \\
\text { (mg/pot) }\end{array}$ & & \\
\hline $\begin{array}{l}\text { (i) Control (without } \\
\text { G. mosseae and P) }\end{array}$ & $18.4^{\mathrm{a}}$ & $0.42^{\mathrm{a}}$ & $9.2^{\mathrm{a}}$ & $0.11^{\mathrm{a}}$ & $1.1^{\mathrm{a}}$ & $5^{\mathrm{a}}$ & nil \\
\hline (ii) Glomus mosseae & $20.8^{\mathrm{b}}$ & $0.68^{\mathrm{b}}$ & $10.7 \mathrm{~b}$ & $0.23^{b}$ & $2.7 \mathrm{~b}$ & $26^{\mathrm{b}}$ & 19 \\
\hline (iii) $2.75 \mathrm{~kg} \mathrm{P} / \mathrm{ha}$ & $20.2^{\mathrm{b}}$ & $0.63^{c}$ & $9.7^{c}$ & $0.21^{\mathrm{b}}$ & $2.3^{\mathrm{b}}$ & $11^{\mathrm{c}}$ & nil \\
\hline (iv) $5.5 \mathrm{~kg} \mathrm{P} / \mathrm{ha}$ & $20.7^{b}$ & $0.69^{b}$ & $10.6^{\mathrm{b}}$ & $0.22^{\mathrm{b}}$ & $2.6^{\mathrm{b}}$ & $19^{d}$ & nil \\
\hline LSD at $5 \%$ level & 1.51 & 0.04 & 0.45 & 0.05 & 0.73 & 1.44 & \\
\hline
\end{tabular}

a,b,c Data bearing different superscripts within the same column differ significantly.

Plant growth was assessed in terms of plant height and dry matter production (Table 1). The highest plant growth in terms of height $(20.8 \mathrm{~cm})$ was significantly $(\mathrm{p}<0.05)$ greater in soils with Glomus mosseae treatment than the control treatment. Dry matter yield of roots $(0.23 \mathrm{~g} / \mathrm{pot})$ and number of root nodules ( 26 nodule/pot) were also significantly ( $\mathrm{p}<$ 0.05 ) higher following treatment with AM fungi. Dry matter yield of shoots was highest 
in case of AM fungi and $5.5 \mathrm{~kg} \mathrm{P} / \mathrm{ha}$. It was significantly $(\mathrm{p}<0.05)$ different from the other treatments, i.e., $2.75 \mathrm{~kg} \mathrm{P} / \mathrm{ha}$ and control (Table 1). Redshaw ${ }^{(1)}$ also observed that Pueraria cover crop was the best suited for upland soils.

Highest nitrogen uptake by roots and shoots were 2.7 and $10.7 \mathrm{mg} / \mathrm{pot}$, respectively, following treatment with AM fungi and varied significantly $(\mathrm{p}<0.05)$ from the other treatments. Lathwell(11) observed that the total nitrogen accumulation in the above ground dry matter of Pueraria varied in a few weeks to a few months form 60 to $112 \mathrm{~kg}$ $\mathrm{N} /$ ha. No mycorrhizal infection was observed in plants which were not inoculated with G. mosseae. The degree of infection correlated well with growth and nitrogen uptake (Table 1).

Dry matter yield and $\mathrm{N}$ uptake by roots and shoots, root nodules of Pueraria were significantly higher in G. mosseae inoculated soils than in uninoculated one. Soil fertility with respect to nitrogen can be maintained by rotating plantings of nitrogen-consuming plants with cultivation of legumes. The nitrogen-fixing bacteria in legumes live in symbiotic association forming a special structure in the roots called root nodule which has a major role in fixing atmospheric nitrogen in.(3) Therefore, it may be concluded that G. mosseae fungi should be maintained to save costly phosphatic fertilizer in upland rubber growing soils of Bangladesh.

\section{References}

1. Redshaw MJ 1982. Leguminous cover crop, the key to sustained agriculture on upland soils in Indonesia. Ind. Agric. Res. Dev. J. 4(4): 117-123.

2. Draft MS 1991. Influences of genotypes, rock phosphate and plant densities on mycorrhizal development and the growth responses of five different crops. Agric Ecosystems Environ. 35: 151-169.

3. Manahan SE 2009. Fundamentals of Environmental Chemistry. 3rd edition, CRC Press, Taylor \& Francis Group, FL, USA. pp.1233.

4. Edgar AT 1958. Manual of Rubber Planting (Malaya). Inc. Soc. Plrs., Kuala Lumpur, Malaysia. pp. 705.

5. Mossse B 1977. The role of mycorrhiza in legume nutrition on marginal soils. In: JM Vincent, AS Whitney and J Bose (eds). Exploiting the legume Rhizobium symbiosis in tropical agriculture. Niftal workshop, Maui, Hawaii. pp. 275-292.

6. Rahman MK and JW Parsons 1997. Effects of inoculation with Glomas mosseae, Azorhizobium caulinodans and rock phosphate on the growth of and nitrogen and phosphorus accumulation in Sesbania rostrata. Biol. Fertil. Soils. 25(1): 47-52.

7. Rahman MK, SM Kabir, GM Mohsin, MD Alam and R Mandal 2008. Effects of inoculation with arbuscular - mycorrhizal fungi and phosphorus on growth, yield and nutrient uptake of mungbean in sterile and non-sterile soils. J. Phytol. Res. 21(2): 247-251. 
8. Koske RE, Gemma JN 1989. A modified procedure for staining roots to detect VA mycorrhizas. Mycol. Res.92: 486-488.

9. Giovannetti $\mathrm{M}$ and B Mosse 1980. An evaluation of techniques for measuring vesiculararbuscular mycorrhizal infection in roots. New Phytol. 84: 489-500.

10. Cresser MS and JW Parsons 1979. Sulphuric-perchloric acid digestion of plant material for the determination of nitrogen, phosphorus, potassium, calcium and magnesium. Anal. Chem. Acta 109: 431-436.

11. Lathwell DJ 1990. Legume Green Manures. Trop. Soils Bulletin. No. 90. Soil Management Collaborative Research Support Progm., North Carolina State University, NC, USA. pp. 30 .

(Manuscript received on 21 July, 2010; revised on 25 October, 2010) 